\title{
DAGMARA BANASIAK
}

Instytut Języka Polskiego, Uniwersytet Warszawski

ORCID 0000-0003-0254-2324

\section{O śmianiu się z czegoś i z kogoś, czyli o przedmiotowym i podmiotowym znaczeniu czasownika śmiać się ${ }^{1}$}

\section{Wstęp}

Czasownik śmiać się nazywa elementarne i uniwersalne ludzkie ${ }^{2}$ doświadczenie psychofizyczne, jakim jest przeżycie komizmu³. Temat (topika, treść) komizmu, odniesienie (przedmiotowe lub podmiotowe) oraz ewentualna (zamierzona lub odebrana) intencja społeczna wpisana w jego kreację wyznaczają szeroki, antonimiczny i niekiedy przez to ambiwalentny zakres ekstensji tego verbum oraz każą badać jego semantykę w ścisłym powiązaniu $\mathrm{z}$ dostępnym kontekstem językowym, treściami presuponowanymi pragmatycznie oraz często wiedzą ekstralingwistyczną, w tym m.in. z teoriami komizmu opracowanymi na gruncie filozofii, socjologii i psychologii.

Zadaniem tego artykułu jest przyjrzenie się na materiale współczesnej polszczyzny wybranym właściwościom składniowo-semantycznym reflexivum tantum śmiać się konstytuującego w polszczyźnie dwa podobne pod względem strukturalnym układy predykatowo-argumentowe, w których predykat czasownikowy wymaga uzupełnienia w postaci frazy przyimkowo-nominalnej wprowadzanej przez przyimek $z$ mający rekcję dopełniaczową. Konstrukcje te mają jednak odmienne znaczenia i realizacje składniowe; denotują także różne scenariusze sytuacyjne, a obecny w nich komizm pełni różne

1 Za wspólny namysł nad tym zagadnieniem dziękuję uczestnikom seminariów „Dociekania semantyczne", które odbywały się na Wydziale Polonistyki Uniwersytetu Warszawskiego w roku akademickim 2019/2020.

2 Por. na ten temat informacje i stanowisko autorki zawarte w przypisie 11.

${ }^{3}$ Choć, naturalnie, nie jest on jedynie wyrazem komizmu. 
funkcje społeczne i wywołuje przeciwstawne skutki (perlokucje). Pozakomiczne odniesienia czasownika śmiać się, obecne w języku polskim np. w konstrukcjach [ktoś] śmieje się [do kogoś] w znaczeniu 'uśmiechać się, cieszyć się na czyjś widok', [ktoś] śmieje się [z kimś] w znaczeniu ‘żartuje z kimś, dobrze się bawi' czy [ktoś] śmieje się z [siebie] w znaczeniu 'potrafi żartować z samego siebie, ma dystans do siebie', nie będą przedmiotem analiz.

Zaproponowany $\mathrm{w}$ tej pracy opis opiera się na modelu struktur predykatowo-argumentowych (tzw. składni semantycznej; dalej: SPA) Stanisława Karolaka (2002). Za pomocą tego instrumentarium możliwa jest precyzyjna analiza wymagań walencyjnych czasownika śmiać się oraz podjęcie próby repartycji ich znaczeń. Dodatkowo narzędzie to pozwala przeprowadzić - jak podkreśla jego twórca - „głęboką i subtelną analizę semantyczną" (Karolak, 2002, s. 99) w duchu podejścia formalnologicznego do badań lingwistycznych. Polega ona na obserwacji otoczenia językowego predykatu (funktora zdaniotwórczego) w celu ustalenia, które z jego składników są elementami implikowanymi (argumentami) - eksplicytnymi lub implicytnymi (niewerbalizowanymi), a które elementami nieimplikowanymi (adiunktami) oraz jakie treści zawierają i zarazem jakie funkcje semantyczne pełnią każde z tych elementów w SPA (tamże, s. 77-170). Jak wiadomo, takie konstrukcje stanowią oś syntagmatyczną każdej wypowiedzi i obok struktury tematyczno-rematycznej oraz informacji presuponowanych składają się na zawartość językową i semantyczną tekstów języka naturalnego. Teoria SPA opiera się na aksjomacie, że „na podstawie dostępnego bezpośredniej obserwacji niższego, formalnego poziomu języków naturalnych da się odtworzyć poziom wyższy, pojęciowy" (tamże, s. 10), co jest jedną z niezbywalnych procedur w poszukiwaniach relacji pomiędzy płaszczyzną pojęciową a jej reprezentacją językową ${ }^{4}$.

Wtórne znaczenie czasownika śmiać się związane z gestem dezaprobaty wyrażanej za pomocą środków satyrycznych zostanie przeanalizowane także w odwołaniu do teorii aktów mowy (Austin, 1962).

Materiał językowy poddany analizie pochodzi częściowo z Narodowego Korpusu Języka Polskiego, częściowo został pozyskany za pomocą wyszukiwarki internetowej Google. Niektóre cytaty są zapisem przygodnych, zasłyszanych przeze mnie wypowiedzi.

O ile mi wiadomo, w językoznawstwie polonistycznym leksemowi śmiać się nie zostało poświęcone żadne odrębne studium ściśle lingwistyczne. Powstało natomiast kilka mniejszych prac na temat czasowników spokrewnionych znaczeniowo ze śmiać się w znaczeniu 'wyrażać wobec kogoś swoją dezaprobatę lub niechęć za pomocą środków komicznych lub parajęzykowych (śmiech)'. Należy do nich m.in. artykuł Macieja Grochowskiego Zarys analizy semantycznej grupy jednostek wyrażajacych negatywne etycznie relacje osobowe (kpina, zniewaga, upokorzenie) oraz Joanny Muszyńskiej $O$ czasowniku kpić. Analiza sktadniowo-semantyczna. Praca Semantyka i składnia czasowników oznaczających akty mowy w języku polskim i czeskim Zbigniewa Grenia również

${ }^{4}$ Teoria ta, rzecz jasna, nie jest wolna od mankamentów metodologicznych i metodycznych, co szczegółowo wykłada np. Dorota Szumska (2017). 
przybliża najważniejsze właściwości jednostek kpić, drwić, szydzić z kogoś jako językowych korelatów aktu mowy.

W artykule świadomie pomijam szczegółowe omówienie definicji słownikowych interesującego mnie leksemu. W przypadku złożonej semantyki zarówno czasownika śmiać się, jak i jego derywatu rzeczownikowego śmiech dane leksykograficzne nie dostarczają satysfakcjonujących wyników, ponieważ często ich punktem wyjścia nie są precyzyjnie przeprowadzone rozpoznania składniowe, moim zdaniem niezbędne do identyfikacji właściwości semantycznych czasowników, ale pokrewieństwo znaczeniowe tych leksemów z innymi.

Odnotuję tylko, że dla ukazania kształtu językowego śmiać się przebadane przeze mnie słowniki polszczyzny ogólnej - SJPD, SJPSzym, ISJP, USJP, WSJP - rejestrują dwa lub trzy znaczenia, hierarchizowane w następujący sposób: pierwszym z nich jest znaczenie reakcji wokalno-mimicznej oznaczającej bycie wesołym, drugie we wszystkich leksykonach jest eksplikowane za pomocą szeregów quasi-synonimicznych 'drwić, szydzić z kogoś, czegoś, wyśmiewać kogoś, coś', a trzecie opatrywane jest definicją 'lekceważyć kogoś, coś, uznawać coś za mało ważne'. W tym miejscu wart zauważenia jest również fakt, że kategoria komizmu lub śmieszności rzadko bywa uwzględniana przez leksykografów jako bodziec stymulujący werbalno-mimiczno-cielesną reakcję. W roli tego bodźca (czy szeroko rozumianej przyczyny śmiechu) leksykografowie podają najczęściej pozytywne afekty w rodzaju wesołości, radości, por. eksplikację dla czasownika śmiać się zawartą np. w SJPDSzym: ‘objawiać wesołość za pomocą swoistego skurczu mięśni twarzy i jednoczesnego wydawania charakterystycznego głosu’ .

\section{Śmiać się z czegoś - przedmiotowe odniesienie komizmu}

Wypowiedzi zbudowane wokół czasownika śmiać się przyłączającego za pomocą przyimka $z$ frazę przyimkowo-nominalną relacjonują w polszczyźnie dwa typy treści. Pierwszy z nich ilustrują następujące cytaty:

(1a) Wszyscy śmiali się z dowcipu o dwóch sąsiadkach staruszkach.

(1b) Cała klatka śmiała się z żartu, który opowiedział sąsiad z dotu.

(1c) Brytyjczycy wciąż śmieją się z Chaplina.

(1d) Czytelnicy śmieją się z jego felietonowej zręczności, podziwiaja ostrość sformutowań.

(1e) Polacy już nie śmieją się z polskich kabaretów.

Znaczenie tych wypowiedzi można najogólniej przedstawić za pomocą deskrypcji 'podmiot odpowiada śmiechem na odpowiednio zinterpretowany bodziec komiczny'.

\footnotetext{
5 O sposobach definiowania znaczeń jednostek leksykalnych śmiać się i śmiech piszę więcej w artykule Rozwój semantyczny wyrazów śmiać się $i$ śmiech (Banasiak, 2017).
} 
Po redukcji argumentów fakultatywnych przyjmuję, że są one skonstruowane wokół następującej SPA ${ }^{6}$ :

\section{[ktoś] śmieje się z [czegoś ABSTR / kogoś ABSTR]}

\section{przy czym:}

[czegoś ABSTR / kogoś ABSTR]: presupozycja pragmatyczna dotycząca kulturowej i społecznej roli bodźca komicznego lub kontekst wskazujący na nią.

Nieprzechodni czasownik śmiać się otwiera w niej lewostronnie miejsce przewidziane na nieusuwalny argument nieprzedmiotowy $k t^{\prime} s^{7}$. Formalnie realizują go wyrazy i wyrażenia o wartości osobowej (komunikowanej wprost za pomocą nazw własnych osobowych, pospolitych osobowych czy zaimków). Analiza płaszczyzny semantycznej tych zdań pokazuje, że podmiot śmiejący się pozostaje „,bierny” w akcie śmiania się, co znaczy, że odpowiada śmiechem na uprzednio zaistniałe i zinterpretowane bodźce komiczne (dowcipy, żarty, postać komika, komiczną sytuację). Zachowanie subiektu w akcie śmiechu, o ile zakładać jego autentyczność, nie ma wpisanej intencji komunikacyjnej i sprowadza się do reakcji fizjologicznej - wyartykułowania któregoś z wariantów onomatopei cha, cha, cha - na zasłyszany, dostrzeżony lub samodzielnie wykreowany komizm prosty w czystej, ludycznej postaci. Szczegółowa rola semantyczna, jaką można by przypisać podmiotowi śmiejącemu się w wypowiedziach opartych na tej SPA, to podmiot doznajacy rozbawienia wywołanego komizmem o funkcji ludycznej.

Prawostronnie czasownik śmiać się w tej konstrukcji składniowej otwiera miejsce na argument w formie dopełniacza mający wartość przedmiotową (np. 1b) Cała klatka śmiała się z żartu, który opowiedział sąsiad z dotu) bądź pozornie (powierzchniowo) nieprzedmiotową (por. zdanie zawarte np. w podpunkcie 1c) Brytyjczycy wciąż śmieją się z Chaplina). Może być on formalizowany w postaci nominalizacji (np. 1a) Wszyscy śmiali się z dowcipu o sąsiadkach staruszkach) lub zdań podrzędnie złożonych. Analiza materiału językowego pokazuje, że argument ten realizują albo wyrazy

${ }^{6}$ Uznaję, że zdanie podrzędne występujące w podpunkcie 1b) pełni funkcję dookreślającą treści wyrażane przez prawostronny argument i nie stanowi odrębnych pozycji składniowych otwieranych przez predykat śmiać się w tym znaczeniu.

${ }^{7}$ Dyskusja dotycząca tego, czy zwierzęta potrafią się śmiać, trwa od co najmniej dwóch stuleci. Pierwsze przesłanki opisywał Karol Darwin w pracy „O wyrazie uczuć u człowieka i zwierząt” (1872), a najnowszych wciąż dostarczają zwierzęcy behawioryści i psychologowie. Sądzę, że w wielu pracach poszukujących u zwierząt przejawów poczucia komizmu często zapomina się o kryterium bardzo przydatnym na gruncie estetyki i humorologii dzielącym śmiech (w rozumieniu widocznej reakcji fizjologicznej) na tzw. naturalny (pozakomiczny), wywołany np. łaskotkami, i nienaturalny (estetyczny), będący świadomym aktem mentalnym konstruowania lub odbierania komizmu (por. na ten temat np. Dziemidok, 1967, s. 11; Plessner, 2007).

Zwierzęce odgłosy mogą wykazywać podobieństwo dźwiękowe i genetyczne do ludzkiego śmiechu „naturalnego”, ale w przypadku śmiechu „estetycznego”, wymagającego zaangażowania intelektualnego, bez którego komizm nie może być wykreowany, zajmuję stanowisko sceptyczne wobec postulatów zawartych w opracowaniach behawiorystyczno-psychologicznych, ale zgodne z ujęciami lingwistycznymi na temat agentywności zwierząt (por. Zaron, 1998, s. 507-513; Bogusławski, 2014). 
lub wyrażenia należące do zakresu nazw gatunkowych bodźców komicznych (np. żart, dowcip, kawat, skecz, komedia itp.), albo - jak w przykładzie 1c) Brytyjczycy wcią̇ śmieja się z Chaplina - inne nazwy, np. osobowe. W przypadku tych drugich należy zauważyć, że zawierają one w swojej strukturze semantycznej skondensowaną presupozycję pragmatyczną. Kondensacji podlega utrwalona i często stereotypowa wiedza na temat fikcyjnych lub rzeczywistych osób czy wydarzeń, które w danej kulturze postrzegane są jako - w odniesieniu do osób - „,bohaterowie komiczni” lub ,ikony komiczne" (por. postać Charliego Chaplina, brytyjskiego komika i aktora kina niemego, w przywołanym wcześniej zdaniu) albo - w odniesieniu do wydarzeń - konwencjonalne scenariusze komiczne. Niezdekodowanie tej presupozycji może prowadzić do tego, że zdanie zostanie odebrane na opak - w znaczeniu 'Brytyjczycy wyśmiewają X-a'8. Jest również tym samym warunkiem zrozumienia tego typu wypowiedzi, które polega na wypełnieniu i zaktualizowaniu jego pragmatycznego odniesienia.

Presupozycje tego typu stanowią także o pozornie, powierzchniowo osobowej wartości argumentu przyłączanego za pomocą przyimka $z$ - śmiech ludyczny wzbudza nie osoba Chaplina per se, ale jej komiczne wcielenie, dobrze znane amatorom kina niemego. Różnica pomiędzy tymi dwoma obliczami Chaplina jest sprowadzalna do różnicy, jaka występuje pomiędzy pojęciem konkretu i abstraktu. W taki też sposób autorzy Słownika syntaktyczno-generatywnego czasowników polskich pod red. Kazimierza Polańskiego opisują dystynkcję pomiędzy właściwościami semantycznymi prawostronnie przyłączanych argumentów - odpowiednio o wartości abstrakcyjnej, w SPA [ktoś] śmieje się [z kogoś / czegoś] w znaczeniu śmiechu wywołanego pobudkami ludycznymi, oraz konkretnej, w SPA [ktoś] śmieje się [z kogoś / czyjegoś], że_w znaczeniu zawoalowanej dezaprobaty wyrażanej za pomocą środków komicznych. Do tego zagadnienia powrócę jeszcze przy okazji omawiania czasownika śmiać się oznaczającego akt mowy.

Oczywiście, we wszystkich przywołanych w tym akapicie wypowiedzeniach mowa jest o interpretowaniu ich znaczenia w oderwaniu od szerszego kontekstu użycia, który może prowadzić do zrozumienia tych wypowiedzi w sensie aksjologicznie odwrotnym, czyli wyrażania negatywnego osądu o kimś lub o czymś należącym do kogoś, por.:

(1b) Dtugo śmialiśmy się z żartu, który opowiedział nam sąsiad z dołu.

$\rightarrow$ Sąsiad z dołu nie ma poczucia humoru i opowiada niezabawne dowcipy. Długo śmialiśmy się z dowcipu, który opowiedział nam ostatnio.

(1e) Polacy już nie śmieją się z polskich kabaretów.

$\rightarrow$ Polacy coraz rzadziej oglądają polskie kabarety i już nie śmieją się z nich.

${ }^{8}$ Na marginesie zaznaczę, że istnieje jeszcze jeden sposób odczytania tej wypowiedzi - 'Brytyjczycy wyśmiewają Chaplina' - w sytuacji, gdy odbiorca wprawdzie zdekoduje właściwie treść presuponowaną pragmatycznie, ale ta wywoła w nim kolejną, będącą jego prywatną oceną co do wartości estetycznej (komicznej) gry aktorskiej Chaplina, która będzie rozbieżna z pozytywną w tym aspekcie oceną suponowaną przez metanadawcę wypowiedzi. 
W tym miejscu nie sposób nie wspomnieć, że dotychczasowe ustalenia, w których dążę do maksymalnej bliskości z faktami tylko językowymi, łączą się też z fenomenem komizmu i komiczności, przekraczającym granice języka, a dokładniej z jego dyskutowanym od kilku wieków na różnych gruntach naukowych odniesieniem - przedmiotowym lub podmiotowym ${ }^{9}$. Ograniczone ramy niniejszej pracy nie pozwalają na wnikliwszą dyskusję nad tą kwestią, dlatego pozostanę przy postawieniu hipotezy, że w świetle danych językowych komiczna referencja może być uchwytna. Umożliwia ją analiza semantyczna kontekstów relacjonujących akt komizmu przez pryzmat znaków językowych, np. czasownika śmiać się, nazywających jego widzialną wokalizację. Zaryzykuję stwierdzenie, że w wypowiedziach, które skonstruowane są wokół SPA [ktoś] śmieje się [z kogoś ABSTR / czegoś ABSTR] w znaczeniu 'odpowiadać śmiechem na bodziec komiczny' obecny w nich komizm ma odniesienie właśnie przedmiotowe w przeciwieństwie do tych użyć, w których czasownik śmiać się oznacza akt mowy wykorzystujący komizm satyryczny jako nośnik służący do ekspresji negatywnego sądu o kimś.

Odpowiedzi wymaga jeszcze jedno pytanie dotyczące charakterystyki prawostronnie implikowanego argumentu w SPA [ktoś] śmieje się [z kogoś ABSTR / czegoś ABSTR]: jaką pełni rolę semantyczną? Sądzę, że należy przypisać mu funkcję przyczyny sprawczej (podobnie jak w przypadku np. SPA o analogicznej budowie [ktoś] cieszy się [z czegoś]) - w przeciwieństwie do roli obiektu, którą pełni analogiczny argument w SPA [ktoś] śmieje się z [kogoś / czyjegoś], że_w znaczeniu 'wyrażać swoją dezaprobatę za pomocą środków komicznych', co będzie tematem rozważań w dalszej części artykułu. Jedną z przesłanek potwierdzającą słuszność tej tezy jest możliwość przekształcenia wypowiedzi skonstruowanych wokół schematu [ktoś] śmieje się [z kogoś ABSTR / czegoś ABSTR] z użyciem derywatu kauzatywnego kogoś śmieszy (ktoś, coś) mającego znaczenie 'pobudzać do śmiechu', por.:

(1a) Wszyscy śmiali się z dowcipu o dwóch sąsiadkach staruszkach.

$\rightarrow$ Dowcip o dwóch sąsiadkach staruszkach śmieszył wszystkich.

(1b) Długo śmialiśmy się z żartu, który opowiedział nam sąsiad z dołu.

$\rightarrow$ Żart, który opowiedział nam sąsiad z dołu, śmieszył wszystkich.

(1c) Brytyjczycy wciąż śmieją się z Chaplina.

$\rightarrow$ Chaplin wciąż śmieszy Brytyjczyków.

(1d) Czytelnicy śmieją się z jego felietonowej zręczności, podziwiają ostrość sformutowań.

$\rightarrow$ Jego felietonowa zręczność śmieszy czytelników.

(1e) Polacy już nie śmieja się z polskich kabaretów.

$\rightarrow$ Polskie kabarety już nie śmieszą Polaków.

${ }^{9}$ Zob. np. dyskusję na ten temat w wyczerpującym opracowaniu Bohdana Dziemidoka (1967) na temat komizmu, scalającym różne poglądy na ten temat. 
Wydaje się, że w wielu przypadkach konstrukcja [z kogoś ABSTR / czegoś ABSTR] bywa używana synonimicznie względem czasownika kauzatywnego śmieszyć (kogoś, coś). Jednak użyta bezkontekstowo jest wieloznaczna, co, jak przekonuje praktyka językowa, może być zbieżnością semantyczną wykorzystywaną na użytek retoryczny.

Jeszcze jedną kwestią ważną w identyfikacji właściwości semantycznych SPA [ktoś] śmieje się [z kogoś ABSTR / czegoś ABSTR] jest rodzaj treści presuponowanych pragmatycznie $\mathrm{w}$ zdaniach afirmatywnych i zanegowanych z użyciem tej konstrukcji ${ }^{10}$. Składają się na nie sądy wartościujące subiektu śmiania się dotyczące oceny danego bodźca komicznego w kategoriach jego wartości estetycznej, fortunności komicznej, a niekiedy również adekwatności do sytuacji społecznej, której był składnikiem ${ }^{11}$. I tak, np. zdanie 1a) zawiera piętrową presupozycję pragmatyczną, którą można przedstawić w taki oto sposób: 'dowcip o dwóch sąsiadkach staruszkach wywołał śmiech u wszystkich, którzy go w danej chwili usłyszeli, a ponieważ śmiech jest widzialnym znakiem m.in. rozbawienia, dowcip, który go wywołał, był śmieszny, zabawny, dobry’. Podobne łańcuszki inferencyjne można utworzyć dla pozostałych wypowiedzi przywołanych w punkcie 1). Negacja w tym samym zdaniu - Nikt nie śmiat się z dowcipu o dwóch sąsiadkach staruszkach - może presuponować informację, że w mniemaniu podmiotu śmiechu usłyszany dowcip był niezabawny, słaby, nieodpowiadający jego upodobaniom komicznym, ponieważ nie doprowadził do wokalizacji śmiechu ${ }^{12}$. Ogólną funkcję pragmatyczną, jaką można przypisać negacji w SPA [ktoś] śmieje się [z kogoś ABSTR / czegoś ABSTR], jest uwypuklenie treści pozostających w presupozycji, dotyczących oceny komizmu obecnego w sytuacji nazywanej za pomocą tego schematu.

\section{Śmiać się z kogoś - podmiotowe odniesienie komizmu}

Inną treść semantyczną i pragmatyczną przejawiają wypowiedzi, w których czasownik śmiać się przyłącza za pomocą przyimka $z$ dwa argumenty: osobowy i zdarzeniowy. Oto przykładowe cytaty:

(2a) Brat Krzysztofa śmiat się z niego, że nie ma dziewczyny. Czy dlatego Krzysztof się zabit?

(2b) Brytyjczycy śmieją się z Polaków, że tak ciężko pracują za grosze [zobacz memy]. (...)

(2c) Reszta [dzieci z klasy - przyp. D.B.] nadal śmieje się z mojego jąkania. (...) Najgorsze jest, jak matpuja moje odpowiedzi.

${ }^{10}$ Mowa tu o negacji zdaniowej wewnętrznej wprowadzanej za pomocą partykuły nie.

${ }^{11}$ Podany przeze mnie zbiór nie wyczerpuje listy możliwych presupozycji, które niesie ze sobą SPA [ktoś] śmieje się [z kogoś / czegoś]. Można wskazać inne, uszczegóławiające wymienione.

12 Jest to jedna z kilku informacji suponowanych przez to zdanie. Inną, niemającą charakteru sądu wartościującego, może być informacja o tym, że brak reakcji śmiechem jest symptomem niezrozumienia usłyszanego dowcipu. 
(2d) Dzieci śmiały się ze mnie, bo byłam nowa i nie wiedziałam, jakie zasady panuja w podgrupkach. Przezywaty mnie , świeżynka”.

(2e) Internet śmieje się z wypowiedzi prezydenta: „Sa tematy trudne, i pan Macron powiedziat, że sa tematy trudne, co mnie bardzo ucieszyło, bo ja té̇ rozumiem, ze sa tematy trudne, ale jak to powiedział kiedyś poeta: Sa w ojczyźnie rachunki krzywd”. Sa tematy trudne, sa tematy trudne i sa tematy.

Czasownik śmiać się występujący w wypowiedziach zebranych w punkcie 2) jest derywatem semantycznym utworzonym na drodze rozszerzeń metonimicznych od śmiać się w znaczeniu 'parajęzykowej odpowiedzi na komizm'. Nazywa nieetyczną sytuację z udziałem dwóch aktantów, w której subiekt śmiechu względem jakiejś właściwości lub własności osobowego obiektu (obecnego lub nie w akcie śmiechu) wyraża swój dezaprobujący stosunek, używając w tym celu środków komicznych w postaci werbalnej, niewerbalnej lub samej reakcji śmiechem. Wspólnym elementem znaczeniowym węzłem semantycznym - pomiędzy znaczeniem wyjściowym a metonimicznie wtórnym jest konkretny składnik definicyjny wyjściowego znaczenia czasownika śmiać się, czyli 'generować wokalizację śmiechu'. Jednak sposób, cel i skutek społeczny jej wywołania są zupełnie odmienne (o czym będzie jeszcze mowa w dalszej części rozważań).

Można powiedzieć, że metonimia leżąca u podstaw przeobrażeń znaczeniowych czasownika śmiać się ma charakter ponadczasowy. Przegląd źródeł etymologicznych i historycznych potwierdza, że wtórne znaczenie metonimiczne czasownika śmiać sie jest obecne w polszczyźnie od doby staropolskiej i żywotne na każdym etapie rozwoju polszczyzny (Banasiak, 2017). Nie sposób ustalić, czy jest ono chronologicznie późniejsze. Wynika to z tego, że jej źródła są niejako „,naturalne” - treść desygnacyjna derywatu semantycznego, który tworzy, jest związana z uniwersaliami dotyczącymi człowieka, jego natury i relacji z innymi. Więź pomiędzy podstawowym znaczeniem i wtórnym nie została nigdy zatracona, czego skutkiem jest ambiwalentna dwuznaczność bezkontekstowych użyć leksemu śmiać się. Na tym tle można by stwierdzić, że jest to metonimia nie w pełni zleksykalizowana semantycznie, żywa i aktualizująca się w języku „tu i teraz”.

Dodatkowo procesowi metonimicznemu towarzyszy przewartościowanie samego aktu śmiechu - od neutralnego pod względem aksjologicznym, mającego pozytywne konotacje związane z uczuciami wesołości i radości, do nieetycznego, prowadzącego do podziałów społecznych.

Procesy metonimiczne będące źródłem znaczenia 'komicznej negacji' obejmują swoim zasięgiem także płaszczyznę syntaktyczną archileksemu śmiać się. Przyjrzyjmy się SPA, wokół której zbudowane są przykłady użyć z czasownikiem śmiać się zgromadzone w punkcie 2), uznając konstrukcje z zaimkowym zapowiednikiem [ktoś] śmieje się [z tego], że_, z nominalizacjami zawierającymi kondensacje pragmatyczne [z czyjegoś] i [z kogoś], ze zdaniami podrzędnymi okolicznikowymi przyczyny [z kogoś, bo / ponieważ_] czy z rematycznym oratio recta [z kogoś / czyjegoś: CYTAT] za jej różne ekwiwalenty formalne: 


\section{[ktoś] śmieje się [z kogoś / czyjegoś], że_}

\section{przy czym}

\section{[kogoś / czyjegoś] ABSTR-}

W przeciwieństwie do SPA, która była przedmiotem moich wcześniejszych rozważań, w tej konstrukcji czasownik śmiać się przyłącza dopełnienie zdaniowe za pomocą spójnika że, komunikujące jednocześnie o przedmiocie komicznej negacji i przyczynie zajścia tego ewaluatywnego aktu. Według klasyfikacji Zofii Zaron jest to $\dot{z} e_{2}$, wprowadzające dictum rematyczne wypowiedzi ${ }^{13}$. Wstawienie tego spójnika do zdań zebranych w punkcie 1) prowadzi do odwrócenia neutralnej pod względem aksjologicznym semantyki „reakcyjnego” śmiać się, nabierającego w tego typu połączeniach znaczenia ‘dezaprobaty komicznej', por. np. zdanie z podpunktu 1c):

\section{Brytyjczycy wciąż śmieją się z Chaplina, że byt dobrym / zabawnym / śmiesznym} komikiem.

Brytyjczycy wciąż śmieja się z Chaplina, ponieważ byt dobrym / zabawnym / śmiesznym komikiem.

Jest to dowód na to, że SPA [ktoś] śmieje się [z kogoś / czyjegoś], że_ (i jej „okazy” składniowe) jest - w przeciwieństwie do [ktoś] śmieje się [z kogoś ABSTR / czegoś ABSTR] - językowym korelatem aktu mowy, a więc stanowi odrębną jednostkę leksykalną. Akt mowy oznaczany tą strukturą składniową zaliczam do typu pośrednich z uwagi na zawoalowany sposób komunikowania negatywnej oceny przez śmiejącego się. Jest ona ukryta w wyspecjalizowanych do tego celu satyrycznych środkach komicznych karykaturze, parodii i jej odmianach, ironii, sarkazmie itp., których budulcem może być język lub inne kody pozawerbalne, składające się na warstwę lokucyjną aktu mowy.

Lewostronnie implikowany argument ma status osobowy i może być formalizowany w rozmaity sposób, podobnie jak w SPA [ktoś] śmieje się [z kogoś ABSTR / czegoś ABSTR]. Jednak ze znaczeniowego punktu widzenia podmiot zdań zebranych w punkcie 2) nie występuje w tej samej roli semantycznej. Nie jest odbiorcą bodźców komicznych, a aktywnym wykonawcą aktu śmiania się z kogoś w tym sensie, że sięga (świadomie bądź nie) po satyryczne środki komiczne, by zademonstrować swoją dezaprobatę wobec rzeczywistych lub wyimaginowanych stanów rzeczy dotyczących jakiejś osoby, które w jego mniemaniu i według jego systemu wartości ,zasługują” na komiczną krytykę lub - mocniej - dyskredytację, nierzadko także w oczach innych, ponieważ odbiegają od przyjętych przez niego szeroko rozumianych norm ${ }^{14}$. Podmioty śmiechu w obu

13 Jest to operator wprowadzający argument zdarzeniowy na prawach cytatu w przeciwieństwie do $\dot{z} e_{1}$, które takiej właściwości nie posiada (por. Zaron, 1980, s. 15-16). Takie wyróżnienie wariantów funkcjonalnych i dystrybucyjnych spójnika że uważam za zabieg przydatny w testach na verba dicendi sensu largo i sensu stricto.

14 To sankcjonowane komicznie ,wykroczenie” może mieć dwa wektory: poniżej lub powyżej przyjętej przez subiekt śmiechu normy (por. Zaron, 1980, s. 12). 
typach wypowiedzi wykazują nie tylko różne typy zachowań - bierne lub aktywne w akcie śmiechu, lecz także odmienny stosunek wobec obecnego w nim komizmu - ten „bierny” jest doznającym przeżycia komicznego, a „aktywny” przypisuje komiczność lub - lepiej - śmieszność obiektowi, wobec którego żywi niechęć.

Prawostronnie implikowany argument w konstrukcjach, w których czasownik śmiać się ma podmiotowe odniesienie, ma inaczej niż w przypadku SPA [ktoś] śmieje się [z kogoś ABSTR / czegoś ABSTR] wartość osobową i konkretną. Użycia, w których nabiera on wartości przedmiotowej (tak jak w zdaniu 2c) Reszta [dzieci z klasy przyp. D.B.] nadal śmieje się z mojego jąkania), występują najczęściej w strukturach znominalizowanych, opartych na metonimii pars pro toto ${ }^{15}$, a więc ich przedmiotowy status jest pozorny. Śmianie się w znaczeniu, które właśnie rozpatruję, jest aktem komunikacyjnym - czynnością werbalną i/lub niewerbalną, wywołującą określone skutki perlokucyjne (zamierzone przez śmiejącego się lub odebrane przez wyśmianego albo projektowane przez samego metanadawcę aktu) w obiekcie śmiechu i w jego odbiorcach (świadkach aktu śmiechu). Nasza wiedza o świecie potwierdza, że w zależności od siły prześmiewczego sądu, jego skali społecznej i częstotliwości występowania komicznych ataków mogą należeć do nich krótkotrwałe pogorszenia nastroju lub długotrwałe skutki w postaci zniszczenia czyjejś samooceny. Konsekwencje zachodzące w psychice obiektu prześmiewczej oceny zaliczam do warstwy perlokucyjnej aktu mowy. Do perlokucji zachodzących poza nim można włączyć reakcję otoczenia, którą nierzadko bywa przyłączenie się do wspólnego śmiechu z podmiotem i w konsekwencji pogorszenie pozycji społecznej i reputacji obiektu w danej społeczności, a nawet wykluczenie z niej.

Na marginesie dodam, że w przypadku semantyki czasownika śmiać się skutki perlokucyjne mają siłę współustanawiającą lub ustanawiającą akt mowy. To m.in. na ich podstawie lub na podstawie ich braku metanadawca wnioskuje, czy daną sytuację należy zaklasyfikować jako akt śmiania się z kogoś, czy jako np. akt żartowania z kogoś, który nie wywołuje żadnych lub tak negatywnych konsekwencji w obiekcie.

Inną niż w przypadku argumentu przedmiotowego lub pozornie nieprzedmiotowego, pełniącego funkcję przyczyny sprawczej w SPA [ktoś] śmieje się [z kogoś ABSTR / czegoś ABSTR], rolę semantyczną należy więc przypisać argumentowi zajmującemu analogiczną składniowo pozycję w SPA [ktoś] śmieje się [z kogoś / czyjegoś], że_. Obiekt komicznej negacji pozostaje biernym odbiorcą osądu, który może wywołać w nim opisane przeze mnie wyżej konsekwencje. Poza tym w przypadku pierwszego, „reakcyjnego” aktu śmiechu komizm był własnością i - co ważne - wartością jego obiektu, co tylko potwierdzał wybuch śmiechu. Osobowy obiekt w konstrukcjach syntaktycznych oznaczających komiczną negację nie jest nosicielem komizmu. Pozorny komizm, a dokładnie jego kompromitująca postać, czyli śmieszność, jest mu przypisywana, narzucana przez śmiejącego się. Są to przesłanki pozwalające stwierdzić, że uszczegółowioną rolą

${ }^{15}$ Pomijam w tym miejscu zdania ogólnofaktyczne i habitualne z czasownikiem śmiać się typu Ludzie śmieją się z jąkania. 
semantyczną obiektu w konstrukcjach, w których czasownik śmiać się wyraża agresję komiczną, jest patiens.

Jak zawsze w przypadku aktów mowy, tak i w tym, oznaczanym za pomocą czasownika śmiać się w znaczeniu 'komicznej dezaprobaty', oprócz relacji między subiektem a patiensem ważną rolę - tu często potrójną - odgrywa trzecia osoba uwikłana w akt śmiechu - jego nadawca wtórny (metanadawca), czyli aktualnie referujący sytuację. Po pierwsze, pełni funkcję typologiczną, polegającą na klasyfikacji danej sytuacji komunikacyjnej jako aktu śmiania się z kogoś, po drugie, ekspresywną, ponieważ zaklasyfikowanie określonego zachowania komicznego jako wyśmiania jest jednocześnie przypisaniem mu negatywnej oceny, a po trzecie, impresywną w tych wypowiedziach, w których dąży do zdemaskowania prześmiewcy lub triumfalnie wtóruje mu we wspólnym śmiechu. W tym sensie punkt widzenia metanadawcy współustanawia semantykę całej wypowiedzi zbudowanej wokół [ktoś] śmieje się [z kogoś / czyjegoś], że_.

Kolejną ważną właściwością interesującej mnie struktury składniowej jest to, że predykat śmiać się nie nakłada w niej żadnych ograniczeń semantycznych na treść przyłączanego argumentu zdarzeniowego (pod warunkiem nieeliptyczności wypowiedzi). Tematem śmiechu mogą być właściwości związane z wyglądem zewnętrznym, osobowością, systemem wartości, zachowaniem, własnościami, stanami rzeczy niepodlegającymi ocenie przez innych lub ocenianymi negatywnie, a także te, które przez innych bywają lub zostałyby ocenione pozytywnie, niejednomyślnie z podmiotem śmiechu. Dlatego zdania:

\section{Niektórzy politycy po cichu śmiali się z Nobla dla Tokarczuk.}

Wielu fanów śmieje się z tego, że pisarz odnióst tak nieprawdopodobny sukces wydawniczy.

w których treść prawostronnego argumentu wypełnia sytuacja oceniana pozytywnie przez innych, nie są sprzeczne znaczeniowo. Jest to pochodną struktury wartościującego sądu będącego konstytutywnym komponentem semantycznym czasownika śmiać się w znaczeniu negacji komicznej. Jego ambiwalentne właściwości, pozwalające na negatywną ocenę pozytywnych stanów rzeczy, są efektem emocjonalno-intelektualnego, subiektywnego kategoryzowania świata, którego wynikiem jest przypisywanie wartości danym przedmiotom lub podmiotom z punktu widzenia własnej hierarchii wartości, przyjętego (świadomie bądź nie) systemu norm, sposobu pojmowania świata i jego wyobrażonej czy pożądanej wizji, a także z powodu niskich pobudek czysto emocjonalnych i interpersonalnych lub braku odpowiedniej socjalizacji. Deprecjonowanie śmiechem jest w tym sensie wyrazem krytyki w ,złym stylu” - niekonstruktywnym i antagonizującym społecznie.

W tej części moich rozważań omówienia wymaga jeszcze kwestia przeczenia i treści presuponowanych przez nie w SPA [ktoś] śmieje się [z kogoś / czyjegoś], że_. Wprowadzenie negacji zdaniowej wewnętrznej za pomocą partykuły nie do wypowiedzi zebranych w punkcie 2) skutkuje powstaniem różnorakich treści, pozostających 
w zakresie presupozycji pragmatycznych zdań, które są odmienne w porównaniu z presupozycjami w zdaniach opartych na konstrukcji [ktoś] śmieje się [z kogoś ABSTR / czegoś ABSTR], por::

(2a) Brat Krzysztofa śmiat się z niego, że nie ma dziewczyny. Czy dlatego Krzysztof się zabit?

$\rightarrow$ Brat Krzysztofa nie śmiał się z niego (z Krzysztofa), że nie ma dziewczyny.

(2b) Brytyjczycy śmieją się z tego, że Polacy pracuja tak ciężko za grosze. (...)

$\rightarrow$ Brytyjczycy nie śmieją się z Polaków, że pracują tak ciężko za grosze.

(2c) Reszta [dzieci z klasy - przyp. D.B.] nadal śmieje się z mojego jąkania. (...)

$\rightarrow$ Reszta dzieci z klasy nie śmieje się z mojego jąkania.

(2d) Dzieci śmiały się ze mnie, bo byłam nowa i nie wiedziałam, jakie zasady panuja w podgrupkach.

$\rightarrow$ Dzieci nie śmiały się ze mnie, bo byłam nowa i nie wiedziałam, jakie zasady panują w podgrupkach.

Jedną z treści presuponowanych może być informacja metanadawcy aktu śmiechu o pozytywnej ocenie postawy podmiotu powściągającego się przed komiczną dyskredytacją takich stanów rzeczy, które zostałyby lub zostały wyśmiane przez innych zgodnie ze stereotypowymi i spodziewanymi scenariuszami zachowań w tego typu sytuacjach społecznych. Funkcją tej negacji jest odwołanie presupozycji pragmatycznej dotyczącej negatywnej oceny podmiotu śmiejącego się z kogoś, komunikowanej przez aktualnie mówiącego. Jej inną rolą może być w niektórych kontekstach zakomunikowanie sprostowania (przez metanadawcę zewnętrznego lub tożsamego ze śmiejącym się) najczęściej po to, by odwołać nieaprobowany etycznie akt mowy i wprowadzić w jego miejsce inny, neutralny aksjologicznie, a prześmiewcę zwolnić tym samym z odpowiedzialności za agresywne zachowanie. Taką funkcję negacji obrazuje wypowiedź śmiejącego się ze zdania 2a), przytoczona w dalszej części artykułu, z którego zaczerpnęłam oba cytaty:

Wcale nie śmiałem sięz niego, nie dokuczatem mu, tylko żartowatem. Przysięgam, $\dot{z}$ e on też żartowat.

\section{Zakończenie}

Wypowiedzi skonstruowane wokół dwóch SPA - [ktoś] śmieje się [z kogoś ABSTR/ czegoś ABSTR] oraz [ktoś] śmieje się [z kogoś / czyjegoś], że_ - relacjonują sytuacje o przeciwnych wektorach komicznych. W pierwszej z nich podmiot jest odbiorcą komizmu, doznającym go, w drugiej zaś sięga po niego, by dać wyraz swojemu negatywnemu nastawieniu wobec kogoś. W pierwszej śmiech jest przyjemnym, ludycznym skutkiem dla wszystkich tych, którzy podzielają określoną wrażliwość estetyczną, a w drugiej satyrycznym lub agresywnym celem. W drugiej sytuacji śmiać się będą ci, 
którzy podzielają określone poglądy na rzeczywistość, postawy wobec niej lub niechęć do kogoś.

Odmienny status i funkcję w każdym z przedstawionych scenariuszy należy przypisać również przyczynom komicznym - w śmiechu ,reakcyjnym” jest ona bodźcem (stimulusem) komicznym, a w śmiechu ,dezaprobującym” stanowi w istocie pretekst do zakomunikowania krytyki lub niechęci ${ }^{16}$.

Te przeciwstawne pod względem aksjologicznym znaczenia czasownika śmiać się, realizowane przez podobne formalnie struktury składniowe, mogą być językowymi dowodami na obraz śmiechu jako zjawiska wewnętrznie sprzecznego. Wokalizacja, która z jednej strony wybrzmiewa jako znak pożądanej społecznie, integrującej zabawy, z drugiej może być nieetycznym gestem wyrażającym antypatię i ujemną ocenę drugiego.

\section{Babci Czesi w podziękowaniu za poczucie humoru}

\section{Bibliografia}

Austin, J.L. (1962), (1993). How to do Things with Words. W: John L. Austin, Mówienie i poznawanie. Rozprawy i wyklady filozoficzne, przeł. B. Chwedeńczuk. Warszawa: Wydawnictwo Naukowe PWN.

Banasiak, D. (2017). Rozwój semantyczny wyrazów śmiać się i śmiech. W: T. Korpysz, A. Krasowska (red.), Komizm historyczny, t. VIII, s. 59-73.

Banasiak, D. (2019). O znaczeniu czasownika wyśmiać (kogoś, coś) i jego użyciu w internetowym dyskursie politycznym. Prace Filologiczne, LXXIII, s. 571-588.

Bogusławski, A. (2014). Studia z filozofii języka (materialy dla stuchaczy z cyklu wykładów monograficznych). Warszawa: ILF UW.

Buttler, D. (1974). Polski dowcip językowy. Warszawa: PWN.

Dziemidok, B. (1967). O komizmie. Warszawa: Książka i Wiedza.

Greń, Z. (1994). Semantyka i składnia czasowników oznaczających akty mowy w języku polskim i czeskim. Warszawa: Slawistyczny Ośrodek Wydawniczy.

Grochowski, M. (1984). Zarys analizy semantycznej grupy jednostek wyrażających negatywne etycznie relacje osobowe (kpina, zniewaga, upokorzenie). Polonica, 8, s. 57-72.

Karolak, S. (1984). Składnia wyrażeń predykatywnych. W: M. Grochowski, S. Karolak, Z. Topolińska, Gramatyka wspótczesnego języka polskiego. Część I: Składnia (s. 11-211). Warszawa: PWN.

Karolak, S. (2002). Podstawowe struktury składniowe języka polskiego. Warszawa: Slawistyczny Ośrodek Wydawniczy.

Hurley, M., Dennet, D. (2017). Filozofia dowcipu. Humor jako siła napędowa umystu. Kraków: Copernicus Center Press.

Muszyńska, J. (2016). O czasowniku KPIć. Analiza składniowo-semantyczna. Prace Filologiczne, LXX, s. 331-339.

Nowakowska-Kempna, I. (1986). Konstrukcje zdaniowe z leksykalnymi wyktadnikami predykatów uczuć. Katowice: Wydawnictwo Uniwersytetu Śląskiego.

Passi, I. (1980). Powaga śmieszności. Warszawa: PWN.

Peisert, M. (2004). Formy i funkcje agresji werbalnej. Próba typologii. Wrocław: Wydawnictwo Uniwersytetu Wrocławskiego.

${ }^{16}$ Za tę konkluzję dziękuję Recenzentom artykułu. 
Plessner, H. (2007). Śmiech i płacz. Badania nad granicami ludzkiego zachowania. Kęty: Wydawnictwo Antyk. Polański, K. (red.) (1994). Stownik syntaktyczno-generatywny czasowników polskich, T. IV. Wrocław: Zakład Narodowy im. Ossolińskich.

Reszka, J. (2001). Predykaty mówienia implikujące pojęcie zła w języku polskim. Kraków: Wydawnictwo Naukowe DWN.

Szumska, D. (2017). Struktura predykatowo-argumentowa jako narzędzie analizy tekstu: pro et contra. Studia z Filologii Polskiej i Stowiańskiej, 52, s. 264-277.

Waszakowa, K. (2008). 'Uśmiech' jako słowo i gest mimiczny. Obraz uśmiechu we współczesnej polszczyźnie. W: R. Grzegorczykowa, K. Waszakowa (red.), Pojęcie - stowo - tekst. Z zagadnień semantyki leksykalnej (s. 151-166). Warszawa: Wydawnictwa Uniwersytetu Warszawskiego.

Wieczorek, U. (1999). Wartościowanie. Perswazja. Język. Kraków: Księgarnia Akademicka.

Zaron, Z. (1980). Ze studiów nad sktadniq i semantyka czasownika. Polskie czasowniki z uzupetnieniem werbalnym oznaczajace relację osobowa z argumentem zdarzeniowym. Wrocław-Warszawa-KrakówGdańsk: Zakład Narodowy im. Ossolińskich Wydawnictwo Polskiej Akademii Nauk.

Zaron, Z. (1998). Czy zwierzę to ktoś? Językowe dowody podmiotowości zwierząt. Prace Filologiczne, XLIII, s. 507-513.

Żygulski, K. (1976). Wspólnota śmiechu. Studium socjologiczne komizmu. Warszawa: PIW.

\section{Skróty źródel}

NKJP - Narodowy Korpus Języka Polskiego. http://www.nkjp.uni.lodz.pl/.

SJPD - Doroszewski W. (red.) (1958-1967). Stownik języka polskiego, T. I-XI. Warszawa: Państwowe

Wydawnictwo Naukowe.

SJPSzym - Szymczak M. (red.) (1995). Stownik języka polskiego. Warszawa: Wydawnictwo Naukowe PWN. ISJP - Bańko M. (red.) (2000). Inny stownik języka polskiego, T. II. Warszawa: Wydawnictwo Naukowe PWN. USJP - Dubisz S. (red.) (2003). Uniwersalny stownik języka polskiego. Warszawa: Wydawnictwo Naukowe PWN.

WSJP - Żmigrodzki S. (red.) (2007-).Wielki słownik języka polskiego PAN. https://www.wsjp.pl/.

\section{STRESZCZENIE}

Stowa kluczowe: śmiać się z czegoś, śmiać się z kogoś, śmiech, składnia semantyczna, struktura predykatowo-argumentowa, akt mowy.

Artykuł wpisuje się w nurt badań nad walencją polskich czasowników w oparciu o model struktur predykatowo-argumentowych opracowany przez Stanisława Karolaka. Jego celem jest analiza statusu formalnego oraz ról semantycznych argumentów przyłączanych przez predykat śmiać się za pomocą przyimka $z$. Analiza danych językowych pokazuje, że predykat ten konstytuuje w polszczyźnie dwie SPA: [ktoś] śmieje się z [kogoś ABSTR / czegoś ABSTR] i [ktoś] śmieje się [z kogoś / czyjegoś], że_o odmiennych właściwościach formalnych, semantyce, nacechowaniu pod względem aksjologicznym oraz różnym odniesieniu przedmiotowym lub podmiotowym - obecnego w akcie śmiechu komizmu. Znaczenie pierwszej z tych konstrukcji można ując jako 'wokalizacja będąca reakcją na komizm ludyczny'. W drugiej czasownik śmiać się jest derywatem semantycznym oznaczającym akt mowy będący 'werbalnym lub niewerbalnym zachowaniem, w którym za pomocą satyrycznych środków komicznych komunikowana jest ujemna ocena osobowego obiektu lub niechęć wobec niego'. 


\section{SUMMARY}

On differences between the predicate-argument structures śmiać się z czegoś (laugh at something) and śmiać się z kogoś (laugh at somebody) based on the Polish linguistic data

Keywords: laughing at something, laughing at somebody, laughter, semantic syntax, predicate-argument structure, act of speech.

The aim of this paper is to discuss the main syntactic and semantic features of the Polish predicate śmiać się (to laugh) within the theory of Semantic Syntax (Karolak 1984, 2002). It forms two, only seemingly similar, predicate-argument structures containing a prepositional phrase connected with the Polish preposition $z+$ Gen. (at): 1) [ktoś] śmieje się z [kogoś ABSTR / czegoś ABSTR] ([somebody] laughs at [somebody ABSTR / something ABSTR]) and 2) [ktoś] śmieje się [z kogoś / czyjegoś], że_([somebody] laughs at [somebody / something what belongs to somebody] + SENT). The analysis shows they are different in terms of status and semantic roles of their arguments, axiological markedness, objective or subjective reference of the humour incorporated in the act of laughter. Also, they denote different semantic scenarios: the first means a vocal and facial reaction to ludic humour, the second constitutes a complex act of speech in which satirical, verbal or non-verbal humour is used as a pretext to communicate the agent's disapproving judgment of the patient, or an antipathetic attitude towards it. 